\title{
Evaluation and Dynamics of the Glacial Runoff of the Rivers of the Ile Alatau Northern Slope in the Context of Global Warming
}

\author{
A.G. Chigrinets, K.K. Duskayev, L.P. Mazur, L.Yu. Chigrinets, S.T. Akhmetova, A.K. Mussina \\ Department of Meteorology and Hydrology, Al-Farabi Kazakh National University, Al-Farabi Ave, 71 -050038, \\ Almaty, Republic of Kazakhstan
}

\begin{abstract}
:
This article deals with the research of glacial runoff. The general characteristic of glaciation of the northern slope of the Ile Alatau is given. The glacio-hydro-meteorological data of the glaciation zone, such as glacier morphometry, air temperature, precipitation, and river runoff, are collected and analyzed. The reconstruction of the annual runoff series of the studied rivers is carried out before the estimated period. The analysis of existing methods for calculating glacial runoff is performed. The glacial runoff of the Ile Alatau rivers is calculated for specific years of a long-term period by two methods: taking into account the runoff from individual morphological parts of the glacier and without dividing it into components (according to ablation formulas). For specific years 1955-2013, glacial runoff is calculated in six options for ten basins of the major rivers and along the slope as a whole, according to the formulas of different authors. The dynamics of glacial runoff is investigated. The trends of the further evolution of glaciation in this area are revealed. New dependences and formulas are proposed for calculating the temperature coefficients of snow and ice melting, as well as for determining the height of the firn line and the ablation value.
\end{abstract}

Keywords - Mountain Watershed, Glacier, Glacial Runoff, Glacial Zone, Ablation, Firn Line, Accumulation Area, Ablation Area, Glacier Tongue, Moraine, Melting Temperature Coefficient, Climate Change, Glaciation Degradation, River Runoff, Mathematical Model.

\section{INTRODUCTION}

The relevance of this work is determined by the need for further research of glacial runoff. It is aimed at improving existing and developing new methods for calculating glacial runoff on a modern basis, as well as evaluating and studying the dynamics of glacial runoff of the Ile Alatau rivers in the context of global warming and glaciation degradation.

\section{MATERIAL RESEARCH METHODS}

The research was carried out on the example of the northern slope of the Ile Alatau, a typical mountainous region of the Northern Tien Shan. The representativeness of this region as a whole and the Kishi Almaty river basin in particular was discussed by I.S. Sosedov [1], A.F. Litovchenko [2], L.P. Mazur [3], E.N. Vilesov, I.S. Sosedov, K.G. Makarevich [4], Konovalov V.G. and Pimankina N.V. [5].
The Ile Alatau is located deep in the mainland. The main watershed ridge reaches a maximum height of 5,017 $\mathrm{m}$ a.s.1. here (Talgar peak). The northern slope of the Ile Alatau stretches from the western watershed of the Uzynkargaly river in the west to the watershed of the Shilik river in the east. In geological and tectonic terms, the Ile Alatau belongs to the Northern Tien Shan fold system. The characteristic features of the climate are continentality, its change with the height of the area, and a significant aggravation of frontal processes. The region's rivers belong to the basin of the Ile river, which flows into Lake Balkash.

The research methodology is based on the geo-hydrological method. The water balance method was also widely used. For clarifying existing and developing new calculation methods, the study used the methods of physical and mathematical modeling, hydrological analogy, interpolation, extrapolation, and mathematical statistics.

The data on water runoff through 2015, taken from hydrological yearbooks and cadastral publications for gauging river sections, was used. The specific water content of the region's rivers varies from $1.5-41 /\left(\mathrm{s} \times \mathrm{km}^{2}\right)$ at altitudes of 1,500 $1,600 \mathrm{~m}$ to $30-33.5 \mathrm{l} /\left(\mathrm{s} \times \mathrm{km}^{2}\right)$ at altitudes of 3,200-3,600 $\mathrm{m}$. The greatest water content is peculiar to the central part of the ridge - the Kishi Almaty river basin, and the smallest - to the river of its western and eastern parts. The variation coefficients of the annual runoff $(\mathrm{Cv})$ of the rivers of this region range within 0.13-1.09.

Precipitation on the territory of the Ile Alatau is mainly measured by Tretyakov's precipitation gauges with petal protection and OSK-2 and M-70 total precipitation gauges. The central, highest part of the ridge is characterized by the greatest amount of precipitation, while to the east and west the amount of precipitation decreases.

Modern glaciation on the northern slope of the Ile Alatau is located between $76^{\circ} 18^{\prime} \mathrm{E}$ and $78^{\circ} 00^{\prime} \mathrm{E}$. The first river in the west with glacier nourishment is the Uzynkargaly river. The Shamalgan, Kaskelen, Aksai, Kishi and Ulken Almaty, Talgar, Yesik and Turgen rivers flow to the east of the Uzynkargaly river. According to the data given in [6], 441 glaciers were registered on the northern slope of the Ile Alatau in 2008, with a total open area of $171.96 \mathrm{~km}^{2}$, an ice volume of $6.897 \mathrm{~km}^{3}$, a moraine area of $91.63 \mathrm{~km}^{2}$ and a buried ice volume of 1.723 $\mathrm{km}^{3}$. For comparison, in the Catalog [10] for 1955, 307 glaciers were recorded with a total open area of $287.3 \mathrm{~km}^{2}$ and an ice volume of $11.540 \mathrm{~km}^{3}$.

To study the changes in mountain-glacier systems, geographic information systems and Earth remote sensing data are 
currently used. Glacier monitoring has also been developed, which can be considered the main stage of the glaciological forecast [6].

In 1955, E.N. Vilesov and R.V. Khonin compiled the first Catalog of Glaciers of the northern slope of the Ile Alatau [10]. The last Catalog for this region was compiled by I.N. Shesterova and A.L. Kokarev by 2013, on the basis of new areas recorded for 2008. Changes in the glaciation area for the period from 1955 to 2008, excluding Fernau stage moraines, are given in Table 1. The highest rates of degradation are observed in the basins of the Shamalgan river (1.08\%/year) and the Ulken Almaty river (0.94\%/year). The lowest rates were noted in the basins of the Aksai river (0.68\%/year) and the Yesik river $(0.66 \%$ /year) $[6,11]$.

Currently, glaciers occupy only the uppermost sections of valleys and mountain slopes. Glaciation areas are located mainly in the height range of 3,600-4,200 m. About $40 \%$ of the glaciation area is occupied by most massive valley and kettlehole glaciers.

Table 1. Changes in the open area of glaciers of the northern slope of the Ile Alatau for the period 1955-2008 [6]

\begin{tabular}{|l|c|c|c|c|c|c|c|c|c|c|}
\hline \multirow{2}{*}{ River basin } & \multicolumn{5}{|c|}{ Area, $\mathrm{km}^{2}$} & \multicolumn{4}{c|}{ Area change } & \multirow{2}{*}{$\mathrm{R}^{2}$} \\
\cline { 2 - 12 } & 1955 & 1974 & 1979 & 1990 & 2008 & $\begin{array}{c}\mathrm{km}^{2} / \mathrm{ye} \\
\text { ar }\end{array}$ & $\mathrm{km}^{2} /$ period & \%/period & $\% /$ year & \\
\hline Uzyn-Kargaly & 12,9 & 11,3 & 10,3 & 9,9 & 7,8 & $-0,09$ & $-4,77$ & -39 & $-0,74$ & 0,985 \\
\hline Shamalgan & 2,6 & 3,1 & 2,2 & 1,8 & 1,3 & $-0,03$ & $-1,59$ & -57 & $-1,08$ & 0,680 \\
\hline Kaskelen & 13,5 & 13,9 & 12,9 & 10,1 & 8,7 & $-0,10$ & $-5,30$ & -41 & $-0,77$ & 0,799 \\
\hline Aksai & 13,5 & 13,3 & 12,5 & 10,2 & 9,3 & $-0,09$ & $-4,77$ & -36 & $-0,68$ & 0,864 \\
\hline Karagalinka & 3,9 & 3,2 & 2,9 & 2,8 & 2,3 & $-0,03$ & $-1,59$ & -39 & $-0,74$ & 0,947 \\
\hline Ulken Almaty & 33,9 & 27,2 & 25,3 & 21,0 & 17,4 & $-0,32$ & $-16,96$ & -50 & $-0,94$ & 0,982 \\
\hline Kishi Almaty & 9,3 & 7,4 & 8,1 & 6,5 & 5,7 & $-0,07$ & $-3,71$ & -39 & $-0,74$ & 0,911 \\
\hline Talgar & 112,5 & 93,6 & 89,2 & 80,7 & 67,4 & $-0,84$ & $-44,52$ & -40 & $-0,75$ & 0,992 \\
\hline Yesik & 49,5 & 41,3 & 36,8 & 35,8 & 31,5 & $-0,33$ & $-17,49$ & -35 & $-0,66$ & 0,924 \\
\hline Turgen & 35,7 & 31,0 & 28,9 & 26,0 & 20,5 & $-0,29$ & $-15,37$ & -43 & $-0,81$ & 0,996 \\
\hline Total & 287,3 & 245,1 & 229,1 & 204,7 & 171,9 & $-2,20$ & $-116,60$ & -41 & $-0,77$ & 0,994 \\
\hline
\end{tabular}

The first data on the magnitude of glacial runoff in the Ile Alatau were obtained by the KazUGMS in 1937-41 [12]. A detailed study of glacial runoff during the International Hydrological Year, the International Hydrological Decade (1965-1974) and in subsequent years was primarily carried out at the Central Tuyuksu glacier, in the Kishi Almaty river basin $[13,14]$.

The Tuyuksu glacier is representative of the northern slope of the Ile Alatau, since it has hypsometric, morphometric (Fig. 1), exposure and other indicators close to the average for the ridge.

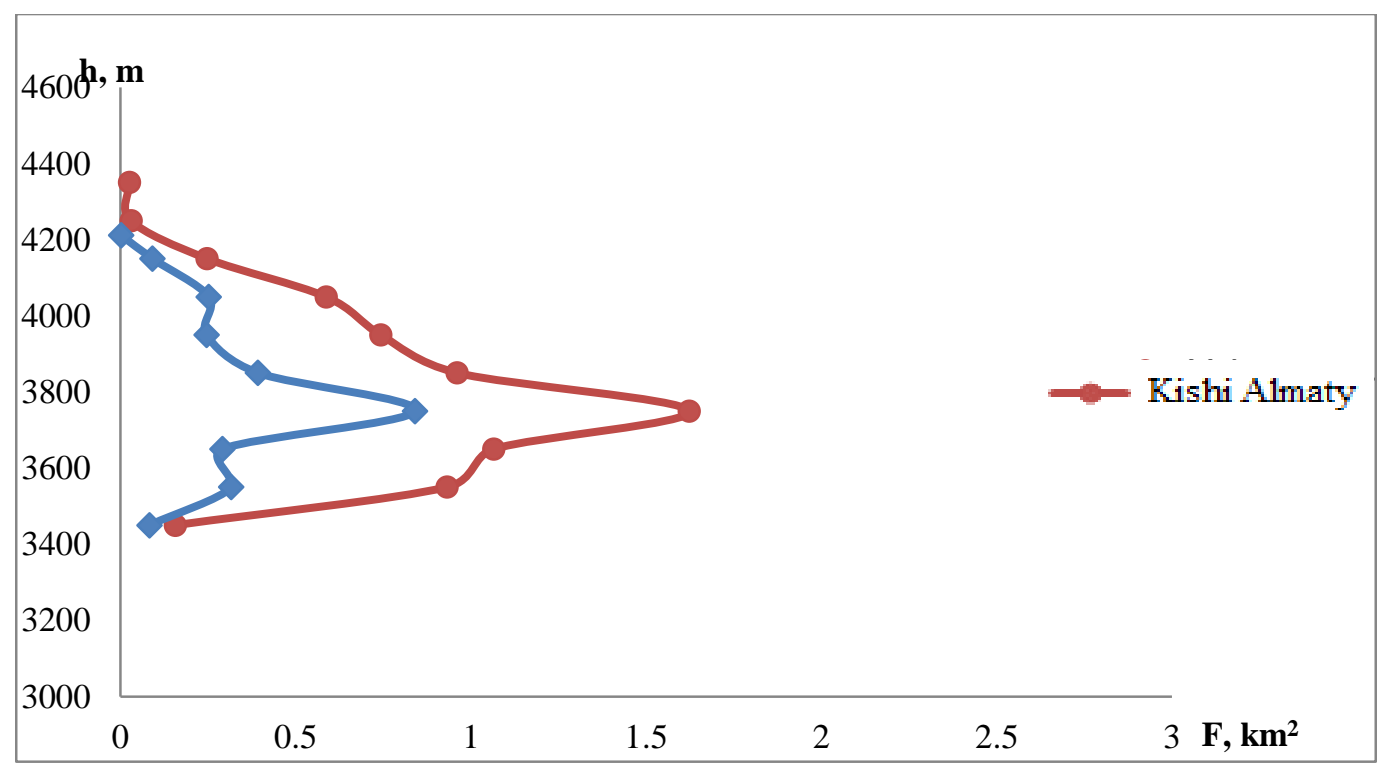

Fig. 1. Combined distribution graph of the glaciation area of the Kishi Almaty river and the Tuyuksu glacier as of 1990 [15] 
The Tuyuksu glacier is the most studied in Kazakhstan and Central Asia and is one of the ten most studied glaciers on Earth.

Glacial runoff is difficult to be determined due to the lack of unity in the interpretation of the concept of "glacial runoff" [4], [14], [16-21]. Our studies [3, 15, 22] used the methodology described in [4] with some refinements to evaluate glacial runoff.

The calculation method according to empirical and semiempirical formulas, using various hydrometeorological characteristics (average summer air temperature, precipitation, etc.) [15], as well as mathematical modeling methods [23-27] are also used to calculate glacial runoff.

To determine glacial runoff from individual morphological parts of the glacial zone, it is advisable to apply the method developed by the Academy of Sciences of the Kazakh SSR [4], with some refinements given in $[14,22]$, using the sums of positive average daily air temperatures and temperature melting coefficients.

The total runoff from the glacial zone $(y)$ according to the indicated method has the following values: runoff from melting seasonal snow in the tongues of glaciers $(s)$ and frontal moraines $(\mathrm{m})$; runoff from melting snow and firn in the accumulation area of glaciers $(f)$; runoff from melting ice in the tongues of glaciers $(i)$ and frontal moraines $(d)$; runoff from subglacial melting on the lower surfaces of glaciers $(g)$, i.e.:

$$
y=f+s+m+i+d+g
$$

According to I.S. Sosedov [1], the error in calculating glacial runoff by formula (1) ranges within $14-20 \%$.

To calculate the ablation of glaciers and glacial runoff, it is essential to correctly determine the vertical gradients of air temperature with increasing terrain height, as well as the temperature coefficients of snow melting $\left(\mathrm{C}_{\mathrm{s}}\right)$, ice $\left(\mathrm{C}_{\mathrm{i}}\right)$ and mixed melting $\left(\mathrm{C}_{\mathrm{mm}}\right), \mathrm{mm} / \mathrm{deg} \times$ day. The temperature gradients of the southern and western exposures are 6-7\% higher than those for the slopes of the northern and eastern exposures [15].

The temperature melting coefficients $C_{i}, C_{s}$ and $C_{m m}$ were also investigated. It is quite clearly seen that the averaged values of
$\mathrm{C}_{\mathrm{i}}, \mathrm{C}_{\mathrm{s}}$ and $\mathrm{C}_{\mathrm{mm}}$ depend on terrain height [26 28]. The equation of the obtained dependence for $\mathrm{C}_{\mathrm{s}}$ has the form:

$$
\mathrm{C}_{\mathrm{s}}=0,005 \mathrm{H}-13,2
$$

where $\mathrm{H}$ is terrain height, $\mathrm{m}$. The equation is justified by actual data in the height range of 3,600-4,200 $\mathrm{m}$ a.s.1.

The equation for determining $\mathrm{C}_{\mathrm{i}}$ is as follows:

$$
\mathrm{C}_{\mathrm{i}}=1,7 \times 1,54^{\mathrm{H}}
$$

where $\mathrm{H}$ is terrain height, $\mathrm{km}$. The equation is justified by actual data in the height range of 3.4-4.1 km a.s.l. The error in the calculation of $\mathrm{C}_{\mathrm{i}}$ was $\pm 16 \%$ [28]

Of great importance for determining ablation and runoff from the glacial zone is the determination of the height of the firn line, which acts as the equilibrium line and separates the nourishment and melting regions of glaciers. The height of the firn line can be evaluated from the data on glacier melting, from aerial photographs and satellite images, as well as from direct observations of its height.

Based on available observational materials on the height of the firn line in the glacial zone of the Kishi Almaty river and N.N. Palgov's concept of the formula [12, 29], L.P. Mazur proposed several formulas for calculating the height of the firn line for specific years $[3,2628,2830]$. The formula proposed in [ 28 30] was refined using more extensive factual material on the height of the firn line. The refined version of the formula has the following form:

$$
\mathrm{F}=3800+70 \Delta \mathrm{t}-0,56 \Delta \mathrm{x}
$$

where $\mathrm{F}$ is the height of the firn line for a particular year, $\mathrm{m}$ a.s.l.; $\Delta \mathrm{t}$ is the deviation from the norm of the air temperature average for VI-VIII at the Mynzhilki weather station for a particular year, in ${ }^{0} \mathrm{C} ; \Delta \mathrm{x}$ is the deviation from the norm of precipitation, in $\mathrm{mm}$ for the period from September of the previous year to August of the current year at the same weather station. The average calculation error by formula (4) is $\pm 25 \mathrm{~m}$.

Fig. 2 shows the combined long-term course of the height of the firn line in the glacial zone of the Kishi Almaty river basin, annual (September-August) precipitation and summer air temperature (average for June-August) at the Mynzhilki weather station. 


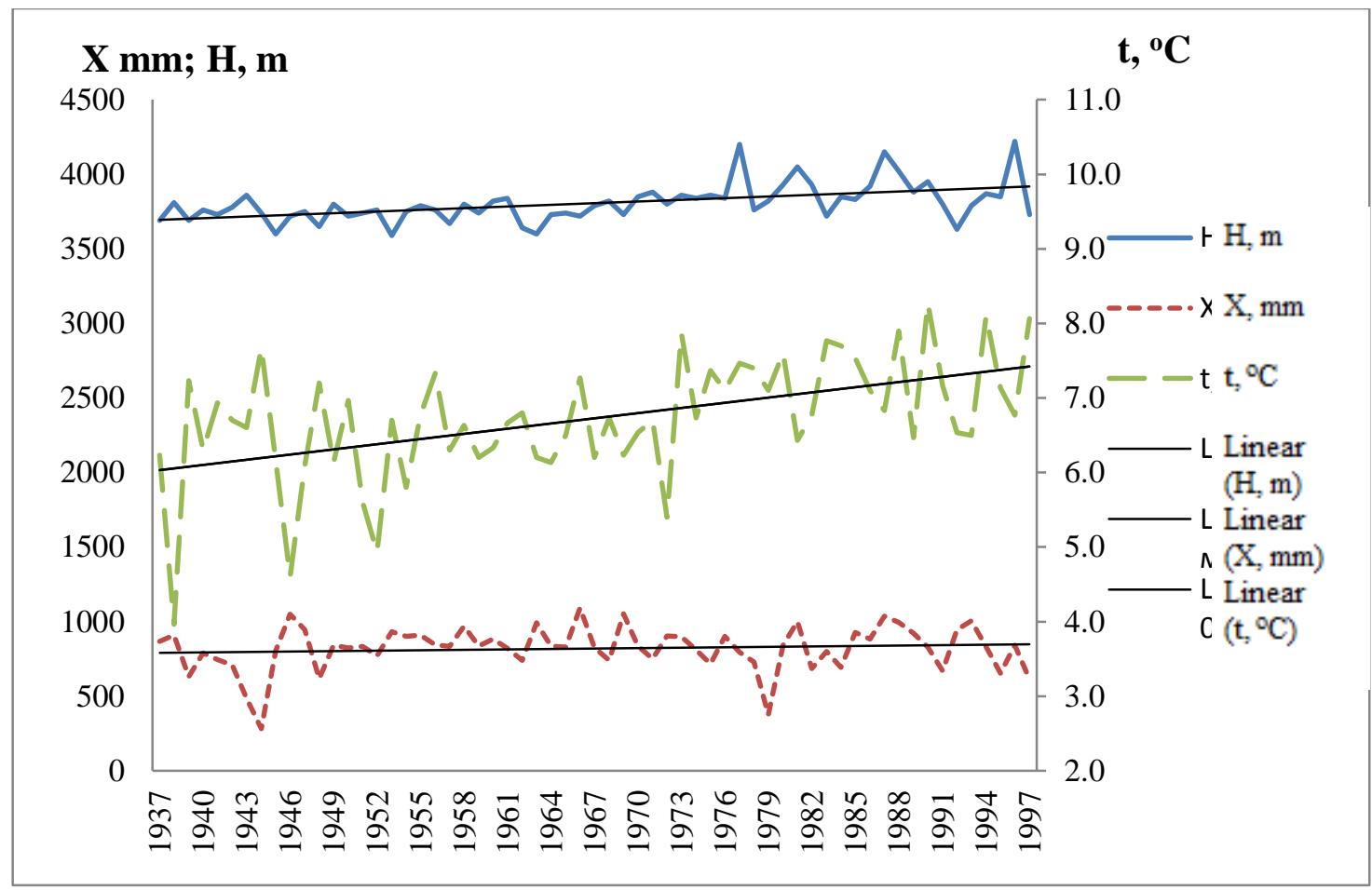

Fig. 2. Combined graph of the long-term course of the height of the firn line $(\mathrm{H}, \mathrm{m})$, precipitation $(\mathrm{X}$, mm) and air temperature $\left(\mathrm{t},{ }^{\circ} \mathrm{C}\right)$ for the period 1937-1997 [15]

It should be noted that using the method [4], earlier, for the first time, we obtained some extensive calculation material on glacial runoff for specific years in the major river basins of the northern slope of the Ile Alatau: $\mathrm{f}=14 \% ; \mathrm{S}=37 \% ; \mathrm{m}=13 \%$; $\mathrm{i}$ $=35 \% ; \mathrm{d}=1 \%$, and the total mean annual volume of glacial runoff amounted to 263 million $\mathrm{m}^{3}$ [3]. When performing calculations for the period 1961-1988, with minor changes in the calculation procedure, the following data were obtained: $\mathrm{f}$ $=15 \% ; \mathrm{S}=35 \% ; \mathrm{m}=14 \% ; \mathrm{i}=35 \% ; \mathrm{d}=1 \%$, and the total mean annual volume of glacial runoff was 274 million $\mathrm{m}^{3}$ [28].

The semi-empirical calculation method of A.N. Krenke and V.G. Khodakov has become widely adopted [31]. As the main argument in calculating annual ablation, they took the average air temperature over the glacier for 3 summer months (JuneAugust). The calculation formula is:

$$
\mathrm{A}_{\mathrm{g}}=(\mathrm{t} \text { June-August }+9,5)^{3}
$$

where $A_{g}$ is the total annual ablation of snow and ice, $\mathrm{mm}$; June-August is the average air temperature for June-August at the calculated height level.

Formula (5) has a global extent. The average error in determining the total annual ablation based on formula (5) in the northern slope of the Ile Alatau according to our calculations is $\pm 35.3 \%$. Therefore, we have derived a regional formula for the Ile Alatau:

$$
\mathrm{A}=644 \times 1,44^{t}
$$

where $A$ is the total annual ablation, $\mathrm{mm}$, at the calculated height level; $\mathrm{t}$ is the air temperature average for VI-VIII at this level, ${ }^{\circ} \mathrm{C}[3,28]$.

\section{RESULTS AND DISCUSSION}

Our studies of glacial runoff began during the International Hydrological Year (1957-1959) and continue to this day. Since there are no actual data on the measurements of glacial runoff, in order to evaluate the methods recommended for its calculations, they were thoroughly analyzed $[3,15,28,30]$.

Empirical and semi-empirical formulas for ablation calculations began to be applied more widely, which was caused by the need to calculate glacial runoff over long periods, to evaluate its dynamics in the context of glaciation degradation and to solve a number of practical problems in using river runoff. In the work of Vilesov E.N. [32], glacial runoff for a specific year in each basin of the Ile Alatau is calculated by the following formula:

$$
\mathrm{W}_{\mathrm{g}}=1,07 \mathrm{~A}_{\mathrm{b}} \times \mathrm{F}_{\mathrm{g}}
$$

where $A_{b}=\left(t_{g}+11,83\right)^{3}$ is the ablation calculated for a height of $3,800 \mathrm{~m}$; $\mathrm{tg}_{\mathrm{g}}$ is the average summer air temperature above the glacier at a height of $3,800 \mathrm{~m} ; 1.07$ is a coefficient that takes into account $7 \%$ of liquid precipitation during the summer period; $3,800 \mathrm{~m}$ a.s.1. is the height corresponding to the average long-term level of the snowline on the macroscope as a whole.

For the first time, according to the method [32], taking into account glaciation degradation and changes in the main climatic factors, we calculated the glacial runoff of ten major rivers of the northern slope of the Ile Alatau for specific years of the period 1955-2013 in six options and considered the dynamics using average glacial runoff values from these options [31], [14], [15, 28, 30].

A.N. Krenke and V.G. Khodakov's formulas: 


$$
\begin{aligned}
& A=\left(t_{g}+9,5\right)^{3} \\
& A=1,33\left(t_{g}+9,66\right)^{2,85}
\end{aligned}
$$

$t_{g}$ is the average temperature of three summer months - JuneAugust.

E.N. Vilesov and V.N. Uvarov's formulas:

$$
A_{b}=\left(t_{g}+10\right)^{3}
$$

$t_{g}$ is the average temperature of three summer months - JuneAugust.

$$
A_{b}=\left(t_{g}+11,83\right)^{3}
$$

$t_{g}$ is the average temperature of five summer months - MaySeptember at a height of $3,800 \mathrm{~m}$ according to the Baltic system of heights.

\section{L.P. Masur's formulas:}

$$
A_{g}=644 \times 1,44^{t_{V I-V I I I}}
$$

where $t_{V I-V I I I}$ is the average temperature of three summer months - June-August;

$$
A_{g}=933 \times 1,46^{t_{I-I X}}
$$

$t_{V-I X}$ is the average temperature of five summer months - MaySeptember.

To calculate the volume of glacial runoff, one should find the value of the glacier open areas for all the major river basins of the northern slope of the Ile Alatau in the period 1955-2013. The ablation areas between their values in the "reference" years (1955, 1979, 1990 and 2008) were calculated taking into account the average air temperatures in these periods and the modular air temperature coefficients for specific years.

The annual ablation layer was multiplied by a factor of 1.07 to take into account the layer of liquid precipitation that fell in summer. The average value of the total glacial runoff of the rivers of the northern slope of the Ile Alatau for six calculation options was 300.4 million $\mathrm{m}^{3}$, with an average deviation of the data obtained for specific options of $\pm 8.2 \%$.

The calculation of river runoff for each year of a multi-year period (1955-2013) is important. The actual data were summarized on average monthly and annual water flow rates for ten rivers, available in the materials of long-term observations on the network of the RSE "Kazhydromet". The work was carried out on the reconstruction of the series of annual runoff and runoff for the growing season of the major rivers. Two statistical series of the same duration of 1955-2013 were obtained: glacial runoff and river runoff in gauging hydrometric sections, combined with temperature fluctuations over three summer months, which are shown in Fig. 3.

High-water years and periods for glacial runoff are accounted for by low-water years of river runoff in gauging sections. The asynchrony of fluctuations in the total glacial runoff and the total river runoff is shown in Fig. 4.

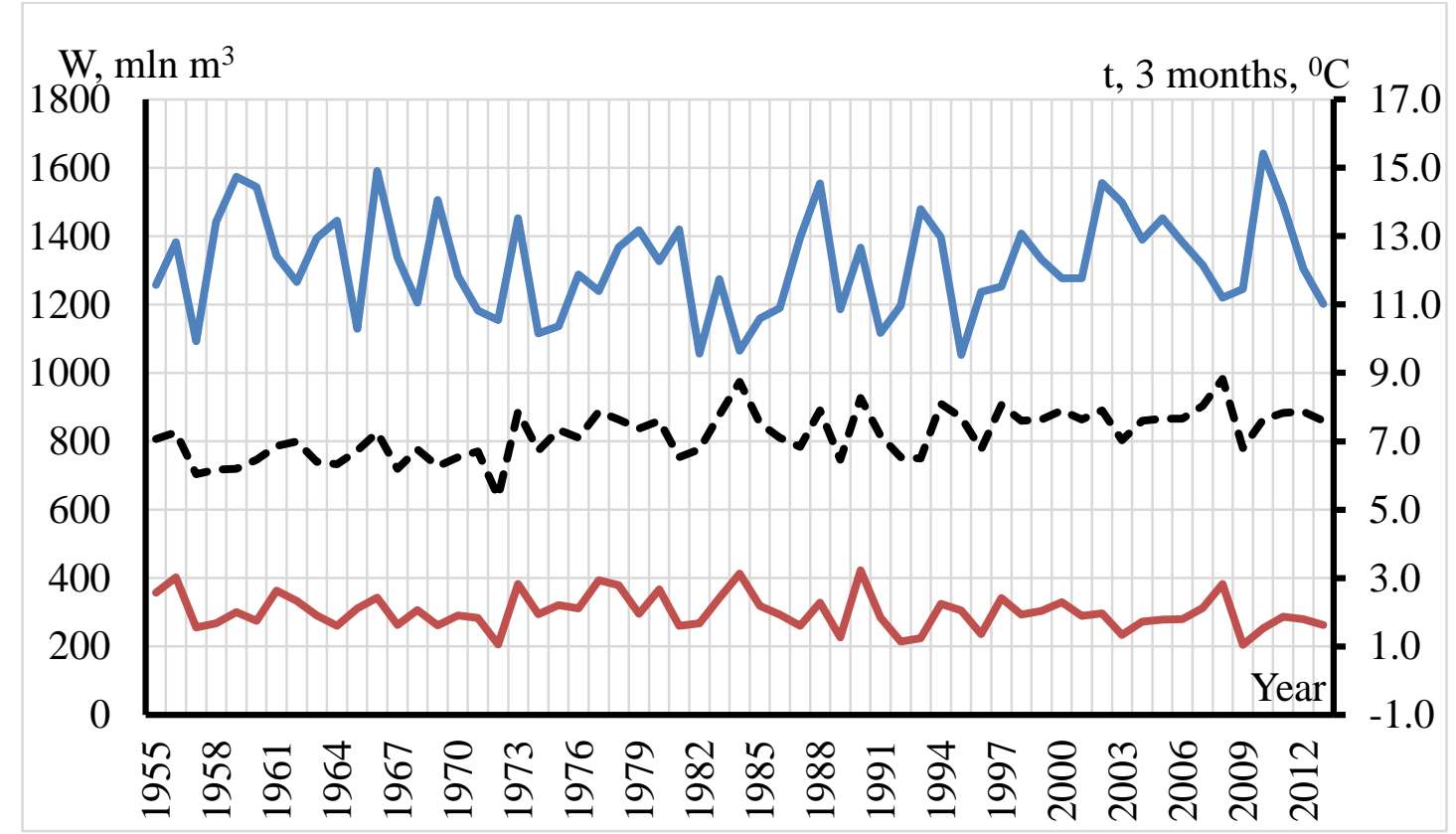

Fig. 3. Combined graph of fluctuations in the total volumes of river runoff, total glacial runoff of the major rivers of the Ile Alatau and the average temperature of three summer months (June-August) for the period from 1955-2013 


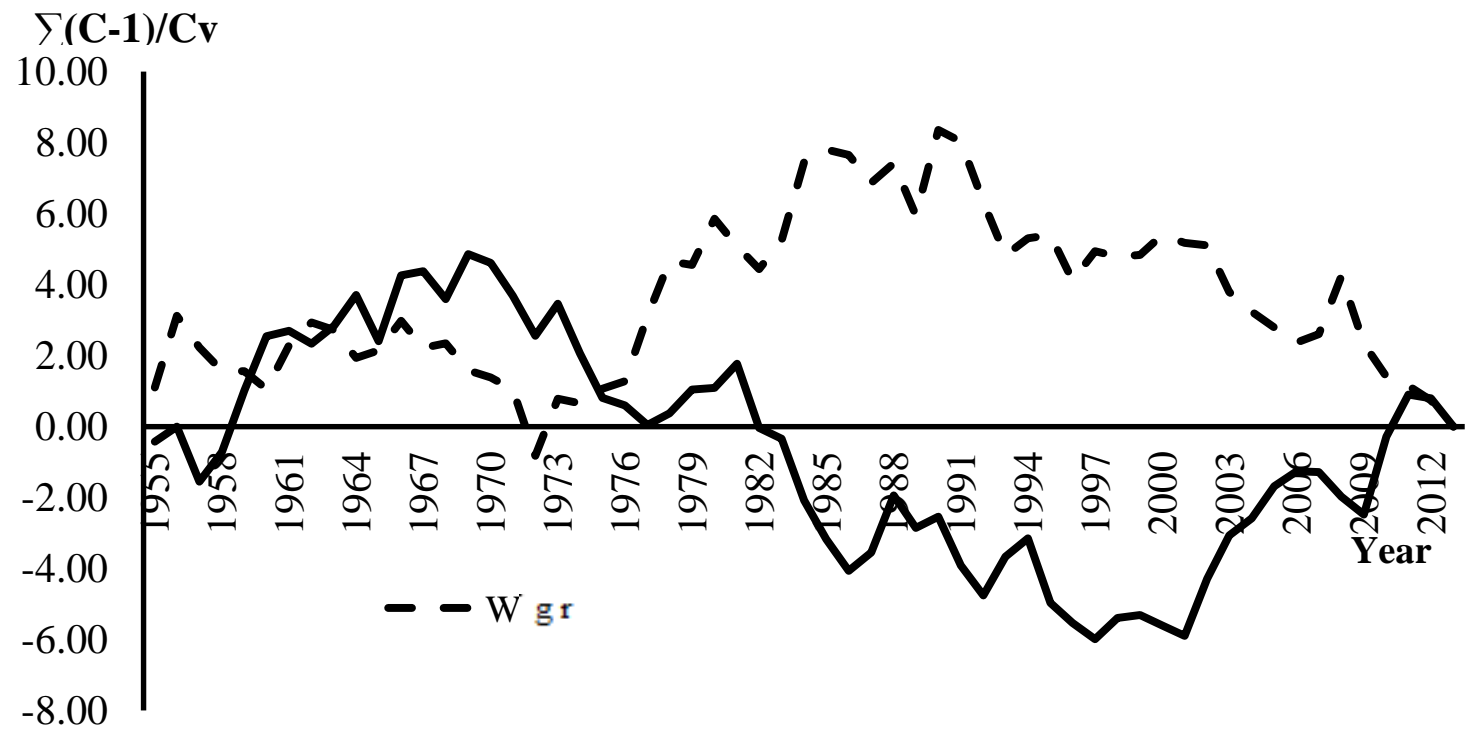

Fig. 4. Combined difference integral curves of the modular coefficients of the total glacial runoff of the rivers of the northern slope of the Ile Alatau for the period 1955-2013

A comparison of the volumes of glacial runoff with annual runoff and runoff for the growing season of the rivers of the northern slope of the Ile Alatau on average for 1955-2013 is shown in Table 2.

Table 2. Comparison of the volumes of glacial runoff $\left(\mathrm{W}, \mathrm{mln} \mathrm{m}^{3}\right)$ with annual runoff and runoff for the growing season for the major river basins of the northern slope of the Ile Alatau on average for the period 1955-2013

\begin{tabular}{|c|c|c|c|c|c|c|c|}
\hline \multirow[b]{2}{*}{ River basin } & \multicolumn{2}{|c|}{ Water flow rate } & \multicolumn{2}{|c|}{ Runoff volume } & \multicolumn{3}{|c|}{ Glacial runoff volume (average) } \\
\hline & $\begin{array}{l}\text { Qaverage } \\
\text { annual, } \\
\mathrm{m}^{3} / \mathrm{s}\end{array}$ & $\begin{array}{l}\text { Qgrowing, } \\
\mathrm{m}^{3} / \mathrm{s}\end{array}$ & $\begin{array}{l}\text { Wannual, } \\
\text { mln } \mathrm{m}^{3}\end{array}$ & $\begin{array}{l}\text { Wgrowing, } \\
\text { mln } \mathrm{m}^{3}\end{array}$ & $\begin{array}{l}\text { Wglacial, } \\
\text { mln } \mathrm{m}^{3}\end{array}$ & $\begin{array}{l}\text { in } \% \text { of } \\
\text { annual }\end{array}$ & $\begin{array}{l}\text { in } \% \text { of } \\
\text { growing }\end{array}$ \\
\hline $\begin{array}{l}\text { Uzunkargaly - Fabrichny } \\
\text { town }\end{array}$ & 3,47 & 4,66 & 109,4 & 72,6 & 13,9 & 13,1 & 19,8 \\
\hline $\begin{array}{l}\text { Shamalgan - Shamalgan } \\
\text { village, } 6 \mathrm{~km} \text { above the } \\
\text { settlement }\end{array}$ & 1,31 & 1,67 & 41,4 & 26,0 & 2,8 & 7,1 & 11,4 \\
\hline Kaskelen - Kaskelen city & 4,24 & 6,20 & 133,8 & 96,8 & 15,6 & 12,0 & 16,7 \\
\hline Aksai - Aksai border & 2,34 & 3,45 & 73,7 & 53,8 & 15,6 & 22,0 & 30,3 \\
\hline Kargaly - Chapaev town & 0,62 & 0,83 & 19,6 & 12,9 & 4,0 & 21,4 & 32,5 \\
\hline $\begin{array}{l}\text { Ulken Almaty - below } \\
\text { the mouth of Terisbutak } \\
\text { river }\end{array}$ & 4,99 & 6,64 & 157,5 & 103,7 & 32,6 & 21,2 & 32,4 \\
\hline $\begin{array}{l}\text { Kishi Almaty - Almaty } \\
\text { city }\end{array}$ & 2,20 & 3,06 & 69,4 & 47,7 & 9,8 & 15,0 & 23,1 \\
\hline Talgar - Talgar city & 10,41 & 15,49 & 328,4 & 241,7 & 117,6 & 36,1 & 49,1 \\
\hline Yesik - Yesik city & 5,01 & 7,31 & 158,0 & 114,0 & 52,2 & 33,7 & 46,9 \\
\hline $\begin{array}{l}\text { Turgen - Tauturgen } \\
\text { village }\end{array}$ & 7,25 & 11,19 & 228,7 & 174,6 & 37,5 & 16,8 & 22,1 \\
\hline Total & - & - & 1319,9 & 943,8 & 300,4 & - & - \\
\hline Average & - & - & - & - & - & 19,8 & 28,4 \\
\hline
\end{tabular}


In the context of the entire glacial system of the northern slope of the Ile Alatau, according to our data, glacial runoff amounted to $22.8 \%$ of the total annual runoff of the major ten rivers of the region on average for the period $1955-2013$ and $31.8 \%$ of the total runoff of these rivers for the growing season.

In 1955-1972, glacial runoff fluctuated around average values over the entire 58-year period. In the second period (19731990), despite the continuing degradation of glaciation, glacial runoff increased, reaching its highest value in 1990 (see Fig. 3 and Fig. 4), which is due to an increase in air temperature and the ablation layer. Since 1991, an increase in the ablation layer with a further increase in air temperature could no longer compensate for the decrease in the area of glaciers.

The glaciological forecast is a scientifically based judgment on the state and development trends of glaciation in the near and distant future [32], [33], [34-38]. According to E.N. Vilesov's method of chronoanalogy [32], the glaciers of the entire glacial system of the northern slope of the Ile Alatau will disappear by 2091.

In our studies, we used data on five reference points (1955, 1974, 1979, 1990, and 2008) and data on areas obtained by interpolation between reference points for all ten basins of the major rivers of the northern slope of the Ile Alatau. We determined the dates of disappearance of glaciers in specific river basins of the region: Shamalgan - 2050; Ulken Almaty 2065; Kargalinka - 2070; Uzynkargaly, Kishi Almaty, Turgen - 2080; Aksai, Kaskelen - 2085; Talgar - 2090; Yesik - 2097, and in the entire glacial system of the northern slope of the Ile Alatau as a whole - by about 2100 . These dates are approximate and possible in the absence of significant climatic changes.

\section{CONCLUSIONS}

The dynamics of glacial runoff is considered using the calculated data for the period 1955-2013. The results can be applied in the practice of hydrological, meteorological, water balance and water management calculations, the preparation of hydrological forecasts, the design of water management structures, as well as the analysis of the conditions for the formation of runoff and the implementation of various theoretical studies for the mountainous conditions of the Ile Alatau. The recommendations and conclusions obtained are physically justified, therefore, can be useful in similar calculations for other mountainous regions.

\section{REFERENCES}

[1] Sosedov IS. Methodology of territorial water balance generalizations in the mountains. Alma-Ata, Nauka, 1976.

[2] Litovchenko AF. Experimental study of the water balance elements of mountain watersheds. Kyiv, Vyshcha shkola, 1986.

[3] Mazur LP. Analysis and calculation of the water balance elements of mountain watersheds (by the example of the northern slope of the Trans-Ili Alatau). The author's abstract of doctoral dissertation. Leningrad, 1989.

[4] Vilesov EN, Sosedov IS, Makarevich KG. Experience in the assessment of glacial river runoff on the northern slope of the Trans-Ili Alatau. Bulletin of the Academy of Sciences of the Kazakh SSR. Alma-Ata, 1973; 11 (343): 25-31.

[5] Konovalov VG, Pimankina NV. Spatial-temporal changes in water balance components on the northern slope of the Trans-Ili AlatauIce and Snow. 2016; 56(4): 453-471.

[6] Kokarev AL, Shesterova IN. Changes in the glacial systems of the northern slope of the Trans-Ili Alatau in the late 20th and early 21 st centuries. Ice and Snow. 2011; 4: 39-46.

[7] Mazur LP. Methodology of calculating river runoff in the study of the water balance of mountain watersheds (by the example of the northern slope of the Trans-Ili Alatau). Problems of the integrated use of water resources of the Ili-Balkhash basin. Alma-Ata, KazSU, 1985.

[8] Mazur LP. On the structure of the water balance of mountain watersheds of the northern slope of the TransIli Alatau Problems of the Geography of Kazakhstan. Alma-Ata, KazSU, 1978.

[9] Chigrinets, AG. Hydrological and environmental assessment of small rivers of the mountain-foothill zone of the Ile Alatau and development of recommendations for their protection. The author's abstract of doctoral dissertation. Almaty, 2006.

[10] The Catalog of Glaciers of the USSR. Volume 13. Issue 2. Part 1. Basins of the left tributaries of the Ili river from the mouth of the Kurty river to the mouth of the Turgen river. Leningrad, Gidrometeoizdat, 1967.

[11] Kokarev AL. Monitoring of the glacial belt of the northern slope of the Ile Alatau using space information and GIS. Bulletin of KazNU. Geographical series. 2009; 2(29): 20-27.

[12] Palgov NN. Modern glaciation in the Trans-Ili Alatau. Alma-Ata, Academy of Sciences of the Kazakh SSR, 1958.

[13] Makarevich KG. Photo Atlas of the Ile Alatau Glaciers (Northern Tien Shan). Pictures of the 20th - early 21st century. Almaty, 2012.

[14] Vilesov EN, Uvarov VN. The evolution of modern glaciation of the Trans-Ili Alatau in the 20th century. Almaty: Kazakh University, 2001.

[15] Mazur LP, Uvarov DV. Research of the glacial runoff of the Kishi Almaty river (Malaya Almatinka). Hydrometeorology and Ecology. 2013; 3: 112-130.

[16] Schulz VL. The rivers of Central Asia. Leningrad: Gidrometeoizdat, 1965. 
[17] Scheglova OP. On a method for determining the height of a snow line on a glacier. Proceedings of SAGU. 1954; 1: $43-47$.

[18] Abalyan TS. River runoff forecast for the Chui basin. Proceedings of TsIP. 1958; 67: 11-16.

[19] Konovalov VG. Calculation and forecast of the melting glaciers of Central Asia. Leningrad, Gidrometeoizdat, 1979.

[20] Semenov VA. On water balance studies in Kazakhstan. Proceedings on the problem of theory and methods of calculating the water balances of river basins. 1970; December 2-4: 242-251.

[21] Semenov VA. Features of the methodology and possibility of water balance calculation in the mountain river basins of the arid zone. Water balance studies in Kazakhstan, KazNIGMI, Issue 50. Moscow, Gidrometeoizdat, 1973.

[22] Mazur LP, Osovskaya VP. On the methodology for calculating runoff from the glacial zone on the northern slope of the Trans-Ili Alatau. Proceedings of KazNIGMI. 1976; 57: 126-133.

[23] Rogov YeI, Kussainov AA, Gumenyuk VV. Physical models of solid mass and related processes in interaction with foundations. Journal of Mechanical Engineering Research and Developments. 2018; 41(2): 65-74.

[24] Rogov YeI, Gumenyuk VV, Rogov A.YE. Adaptive working technology of technogenic metal deposits at the place of their bedding. International Journal of Civil Engineering and Technology. 2018; 9(7): 1831-1850.

[25] Rybak OO. Overview of methods for forecasting glacier runoff under conditions of lack of source data. Earth Sciences. 2018; 12(78): 34-41.

[26] Linsbauer A, Paul F, Haeberli W. Modeling glacier thickness distribution and bed topography over entire mountain ranges with GlabTop: Application of a fast and robust approach. Journal of Geophysical Research. 2012; 117: F0007.

[27] Clarke G, Anslow FS, Jarosh AH. Ice Volume and Subglacial Topography for Western Canadian Glaciers from Mass Balance Fields, Thinning Rates, and a Bed Stress Model. Journal of Climate. 2013; 26: 4282-4303.

[28] Mazur LP. Glacial runoff calculation in the conditions of the Trans-Ili Alatau. Issues of the hydrological and hydraulic regime of the rivers of Kazakhstan. Almaty: Al-Farabi Kazakh State University, 1997.

[29] Palgov NN. The firn line as an indicator of the hydrological regime of glaciers. Thermal and water regime of glaciers of Kazakhstan. Alma-Ata, Nauka. 1969.

[30] Mazur LP. On the calculation of glacier ablation in the northern slope of the Trans-Ili Alatau. Use and protection of natural resources of Kazakhstan. AlmaAta, KazGU, 1979.
[31] Krenke AN, Khodakov VG. On the relationship between surface glacier melting and air temperature. MGI. 1966; 12: 153-164.

[32] Vilesov EN. Dynamics and current state of glaciation of the mountains of Kazakhstan. Almaty, Kazakh University, 2016.

[33] Dobrov GM. Forecasting of science and technology. Moscow, Nauka, 1977.

[34] Sorg A, Bolch M, Stoffel M. Climate change impacts on glaciers and runoff in Tien Shan (Central Asia). Nature Climate Change. 2012; 2: 725-731.

[35] Huss M, Hock R. Global-scale hydrological response to future glacier mass loss. Nature Climate Change. 2018; 8: $135-140$.

[36] Barandun M, Huss M, Usubaliev R. Multi-decadal mass balance series of three Kyrgyz glaciers inferred from modelling constrained with repeated snow line observations. The Cryosphere. 2018; 12: 1899-1919.

[37] Huss M, Jouvet G, Farinotti D. Future high-mountain hydrology: a new parameterization of glacier retreat. Hydrology and Earth System Sciences. 2010; 14: 815829.

[38] Ziyadin S, Shash N, Levchenko T, Khudaibergenova S, Yessenova G. Modeling of resultant effects in assessment of innovative activity of the hotel organization. Entrepreneurship and Sustainability Issues. 2019; 6(4): 2180-2193. 